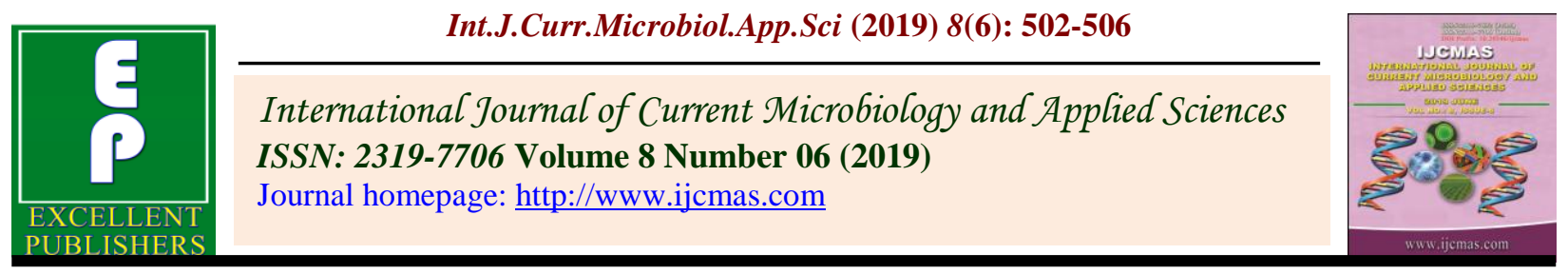

Original Research Article

https://doi.org/10.20546/ijcmas.2019.806.057

\title{
Bench Mark Values for Grain Iron Content in Finger Millet (Eleusine coracana (L.) Gaertn.)
}

\author{
Y.A. Nanja Reddy ${ }^{1,2 *}$, T. Lavanyabai ${ }^{2}$, Prabhakar $^{2}$, V. Ramamurthy ${ }^{4}$, \\ T.C. Chame Gowda ${ }^{3}$, A.G. Shankar ${ }^{1}$ and M.V.C. Gowda ${ }^{2}$ \\ ${ }^{1}$ Department of Crop Physiology, University of Agricultural Sciences, GKVK, Bangalore- \\ 560065, Karnataka, India \\ ${ }^{2}$ AICRP on Small Millets, University of Agricultural Sciences, GKVK, Bangalore-560065, \\ Karnataka, India \\ ${ }^{3}$ Department of Soil Science \& Agricultural Chemistry, University of Agricultural Sciences, \\ GKVK, Bangalore-560065, Karnataka, India \\ ${ }^{4}$ NBSS \& LUP, ICAR, Hebbal, Bengaluru -560024, India \\ *Corresponding author
}

\begin{tabular}{|l|}
\hline Ke y w o r d s \\
Finger millet, Iron, \\
AAS \\
\hline Article Info \\
\hline $\begin{array}{l}\text { Accepted: } \\
\text { 07 May } 2019 \\
\text { Available Online: } \\
\text { 10 June } 2019\end{array}$ \\
\hline
\end{tabular}

A B S T R A C T

Finger millet is an excellent source of mineral elements specifically calcium and iron. The iron content in the ruling variety, GPU-28 is $5.47 \mathrm{mg} / 100 \mathrm{~g}$. Identification of germplasm lines superior to GPU-28 would help in identifying nutritionally superior genotypes and also to serve as genetic resource for recombination breeding. For such screening, use of appropriate procedure and bench mark values are highly useful. Hence, the present study was conducted to confirm the estimation procedure and to arrive at bench mark values for grain iron content in popular varieties. The elemental analysis was carried out in two laboratories. The results of the study indicated a positive correlation between the two laboratories for iron content and confirmed the appropriateness of procedure used for digestion and AAS estimation. Among the varieties, the iron content was significantly superior in GPU-67 (6.52 mg/100g) compared to the GPU-28 and hence, this variety and grain iron content can be considered as a variety with bench mark value for screening large number of germplasm lines.

\section{Introduction}

Finger millet is predominantly cultivated in arid and semiarid regions of Africa and Asian countries as one of the staple food crop. In Karnataka, the crop (widely used Cv. GPU28, MR-1, MR-6, L-5, KMR-340 etc.) is mostly cultivated as kharif crop in an area of 6.3 lakh ha with productivity of $1759 \mathrm{~kg} \mathrm{ha}^{-1}$ (Anon, 2013). It is a promising source of micronutrients with high dietary fibre (1520\%), calcium (264-365 $\mathrm{mg} / 100 \mathrm{~g})$, magnesium (66-130 mg/100g), iron (3.60$7.31 \mathrm{mg} / 100 \mathrm{~g})$, sodium $(0.60-0.95 \mathrm{mg} / 100 \mathrm{~g})$ and potassium (294-1160 mg/100g) with relatively lower quantities of anti-nutritional factors such as tannins and phytate (0.30 and $0.34 \mathrm{mg} / 100 \mathrm{~g}$ respectively) (Gopalan et al., 2002; Chethan and Malleshi, 2007; Shashi et al., 2007). Among the micronutrients, iron 
and zinc are imperative. The iron deficiency lead to anaemia (WHO, 2015) and; more than $80 \%$ of pregnant women in developing countries do suffer from iron deficiency especially in rural mass (Kruger et al., 2012). Hence, fortification of foods with micronutrients especially iron and the use of diversified foods rich in iron are common practices being followed. The other approach could be bio-fortification of crop which is cost effective in long run, for which identification of genetic resources rich in iron is the basis and the genotypic variation has been evidenced (Kazi and Auti, 2017). However, preliminarily it is pertinent to quantify the element in released varieties which are under cultivation and human consumption. The data pertaining to released varieties is not available and such data would be useful for future bio-fortification studies. Therefore the experiment was planned to quantify the grain iron content in released varieties of finger millet.

\section{Materials and Methods}

Seventeen released varieties of finger millet were grown during monsoon, 2017 with protective irrigation at GKVK farm, University of Agricultural Sciences, Bengaluru, Karnataka. The grain was harvested at maturity and used for the estimation of iron content. The grain samples were de-husked and washed thoroughly with acetone followed by double distilled water. Such washed grains were oven dried at $65^{\circ} \mathrm{C}$ for 2 hours. These samples were weighed $(0.50 \mathrm{~g})$ using three decimal balance. Such weighed samples were placed in $100 \mathrm{ml}$ capacity conical flask and pre-digested overnight adding $10 \mathrm{ml}$ of concentrated nitric acid. The next day, the pre-digested samples were added with di-acid mixture $\left(\mathrm{HNO}_{3}\right.$ and Perchloric acid; 9:4 respectively) and open digested on hot plate in acid fume chamber until the sample is completely digested (white semi-solid) to a two to three millilitre. Then cooled and volume was made up to $50 \mathrm{ml}$ with double distilled water. These samples were fed to Atomic Absorption Spectrophotometer (AAS) using standard curve made for the element using Merck laboratory chemical. These samples were estimated for iron, using AAS at two laboratories namely, Nutrition Laboratory, Department of Crop Physiology, GKVK and the National Bureau of Soil Science and Land Use Planning for data confirmation. The calculations for the element are as follows.

Fe content $(\mathrm{ppm})=$

Graph ppm X Vol. of digested sample (ml)

Weight of sample (mg)

\section{Results and Discussion}

The grain iron content of finger millet varieties did not differ between the laboratories (Fig. 1). The correlation between two laboratories for grain for iron is positive and significant (Fig. 2). These results suggest that the varieties are stable for their grain iron content and; the procedure adopted for digestion of samples and use of AAS for measuring iron can be adopted for screening of large number of germplasm of finger millet. This is in confirmation with Netravati et al., (2018), where they have digested the sample using hot plate method and measured elements using ICP-OES (Table 1).

The grain iron content ranged from 3.98 to $6.52 \mathrm{mg} / 100 \mathrm{~g}$ and highest being in variety GPU-67 $(6.52 \mathrm{mg} / 100 \mathrm{~g})$ and is significantly higher than GPU-28 (5.47 mg/100g). Similarly, Babu et al., (1987) reported grain iron content ranged from 3.3 to $14.8 \mathrm{mg} /$ 100g. Further, Singh and Srivastava (2006) reported iron content of 16 finger millet varieties ranged from 3.61 to $5.42 \mathrm{mg} / 100 \mathrm{~g}$. 
Table.1 Genotypic variation in zinc and iron content in popular finger millet varieties

\begin{tabular}{|l|c|}
\hline Variety & $\begin{array}{c}\text { Grain Fe } \\
(\mathbf{m g} / \mathbf{1 0 0 g})\end{array}$ \\
\hline Location & Pooled \\
\hline GPU-48 & 3.98 \\
\hline RAU-8 & 4.06 \\
\hline KOPN -330 & 4.15 \\
\hline GPU-66 & 4.28 \\
\hline KMR-316 & 4.35 \\
\hline POORNA & 4.59 \\
\hline VL-146 & 4.66 \\
\hline SHARADHA & 4.75 \\
\hline VR-708 & 4.79 \\
\hline VL-347 & 5.06 \\
\hline INDAF-15 & 5.13 \\
\hline L-5 & 5.17 \\
\hline PES-110 & 5.18 \\
\hline PR-202 & 5.43 \\
\hline GPU-28 & $\mathbf{5 . 4 7}$ \\
\hline KEMPURAGI & 5.66 \\
\hline GPU-67 & 6.52 \\
\hline Mean & $\mathbf{4 . 9 9}$ \\
\hline CD @ 5 \% & 0.63 \\
\hline SEm \pm & 0.22 \\
\hline C.V. (\%) & 7.7 \\
\hline
\end{tabular}

Fig.1 Finger millet grain iron content across the laboratories

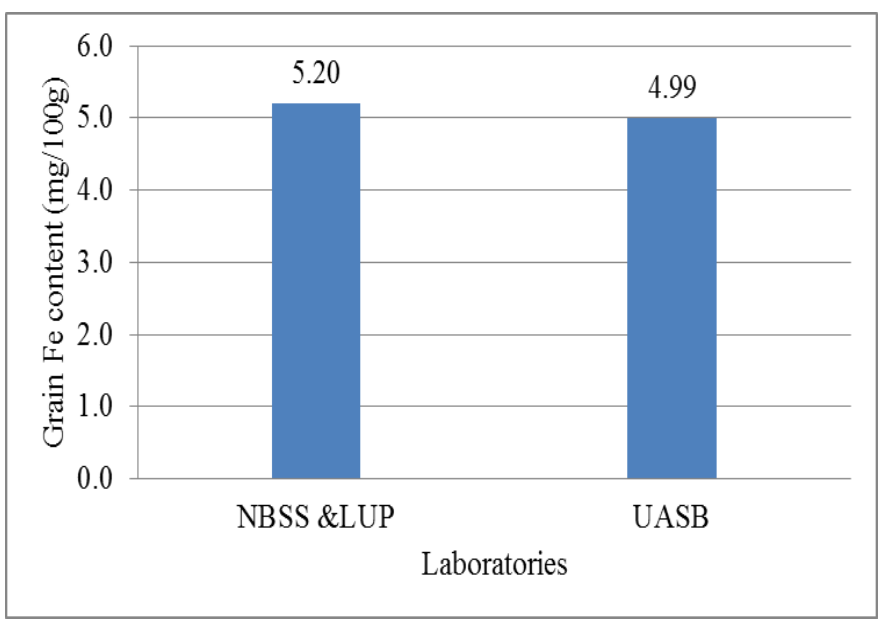


Fig.2 Relationship between grain iron content between two laboratories

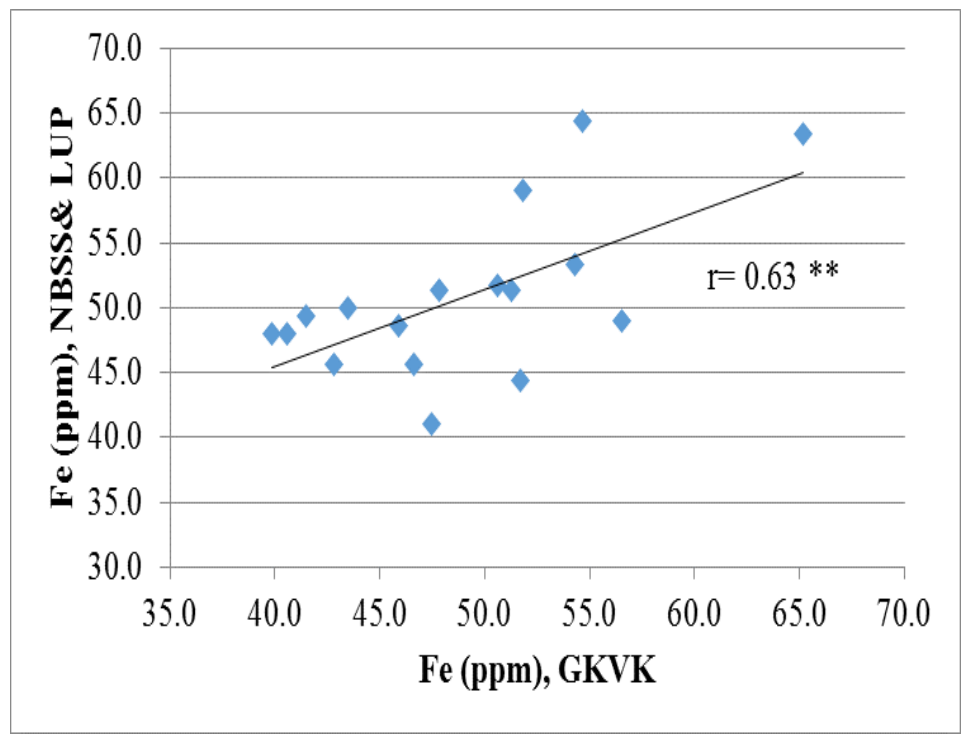

In a recent study, Wafula et al., (2018) reported grain iron content ranged from 3.1 to $4.3 \mathrm{mg} / 100 \mathrm{~g}$. Similar result of $3.9 \mathrm{mg} / 100 \mathrm{~g}$ grain of iron has been reported in another study by Kumar et al., (2016). Louwagie (2016) also reported a range of total iron content from 0.94 to $1.73 \mathrm{mg} / 100 \mathrm{~g}$. Varietal differences observed in different studies could be due to genetic, soil, environmental factors (Shashi et al., 2007; Singh and Raghuvanshi, 2012). Hence, the grain iron content (6.52 $\mathrm{mg} / 100 \mathrm{~g}$ ) obtained in Cv. GPU-67 following the current methodology, can be used as bench mark value for screening large germplasm to identify genetic resources rich in grain iron content.

\section{Acknowledgments}

Author wish to express sincere thanks for the financial support of ICAR, New Delhi under "CRP on bio-fortification of crops" and to Ms. K.R. Manasa, Technical Assistant, Nutritional Laboratory, Department of Crop Physiology, UAS, GKVK for her support in elemental analyses.

\section{References}

Anonymous. 2013. Annual Report, AICRP on Small Millets. 2013.

Babu, B.V., Ramana, T. and Radhakrishna, T.M. 1987. Chemical composition and protein in hybrid varieties of finger millet. Indian Journal of Agricultural Sciences. 57 (7): 520-522.

Kumar, A., Metwal, M., Kaur, S., Gupta, A.K., Puranik, S., Singh, S., Singh, M., Gupta, S., Babu, B.K., Sood, S. and Yadav, R. 2016. Nutraceutical value of finger millet [Eleusine coracana (L.) Gaertn.] and their improvement using omics approaches. Frontiers in Plant Science. 7 (934): 114.

Chethan, S. and Malleshi, N.G. 2007. Finger millet poly phenols: characterization and their nutraceutical potential. American Journal of Food Technology. 2: 618-629.

Gopalan, C., Rama Sastri, B.V. and Balasubramanian, S.C. 2002. Nutritive value of Indian foods. Indian Council of Medical Research, Hyderabad, 
India.

Kazi, T. and Auti, S.G. 2017. Screening of higher mineral containing finger millet landraces from Maharashtra. International Journal of Food Science and Nutrition. 2(3): 21-25.

Kruger, J., Taylor, J.R.N. and Oelofse, A. 2012. Effects of reducing phytate content in sorghum through genetic modification and fermentation on in vitro iron availability in whole grain porridges. Food Chemistry. 131(1): 220-224.

Louwagie, L. 2016. Iron and zinc bioaccessibility of finger millet porridges from Zimbabwe. M.Sc. Thesis submitted to the Faculty of Bioscience Engineering, University of Gent, Belgium.

Netravati, H., Geetha, K., Vikram, S.R., Nanja, Y.A., Joshi, N. and H. B. Shivaleela, H.B. 2018. Minerals content in finger millet [Eleusine coracana (L.) Gaertn]: A future grain for nutritional security. International Journal of Current Microbiology and Applied Sciences. Special Issue 7: 3448-3455.
Shashi, B. K., Sharan, S., Hittalmani, S., Shankar, A. G. and Nagarathna, T.K. 2007. Micronutrient composition, anti nutritional factors and bioaccessibility of iron in different finger millet (Eleusine coracana) genotypes. Karnataka Journal of Agricultural Sciences. 20: 583-585.

Singh, P. and Raghuvanshi, R. S. 2012. Finger millet for food and nutritional security. African Journal of Food Science. 6(4):77-84.

Singh, P. and Srivastava, S. 2006. Nutritional composition of sixteen new varieties of finger millet. Journal of Community Mobilization and Sustainable Development. 1(2): 81-84.

Wafula, W.N., Korir, N.K., Ojulong, H.F., Siambi, M. and Onyango, J.P. 2018. Protein, calcium, zinc, and iron contents of finger millet grain response to varietal differences and phosphorus application in Kenya. Agronomy. 8 (24): 1-9.

WHO. 2015. WHO Micronutrient deficiencies, 2015. http:// www.who.int/nutrition/topics/ida/en/i ndex.html.

\section{How to cite this article:}

Nanja Reddy, Y.A., T. Lavanyabai, Prabhakar, V. Ramamurthy, T.C. Chame Gowda, A.G. Shankar and Gowda, M.V.C. 2019. Bench Mark Values for Grain Iron Content in Finger Millet (Eleusine coracana (L.) Gaertn.). Int.J.Curr.Microbiol.App.Sci. 8(06): 502-506. doi: https://doi.org/10.20546/ijcmas.2019.806.057 